\title{
The Psycho-Didactic Approach in Religious and Moral Education. Towards Personal Growth and Positive Mental Health of Students
}

\author{
Małgorzata Steć ${ }^{1, *}$ and Małgorzata Maria Kulik ${ }^{2}$ \\ 1 Institute of Psychology, Jesuit University Ignatianum, 26 Kopernika Street, 31-501 Kraków, Poland \\ 2 Institute of Psychology, University of Szczecin, 70-451 Szczecin, Poland; malgorzata.kulik@usz.edu.pl \\ * Correspondence: malgorzata.stec@ignatianum.edu.pl
}

Citation: Steć, Małgorzata, and Małgorzata Maria Kulik. 2021. The Psycho-Didactic Approach in Religious and Moral Education. Towards Personal Growth and Positive Mental Health of Students. Religions 12: 424. https://doi.org/ $10.3390 /$ rel12060424

Academic Editor: Dariusz Krok

Received: 23 April 2021

Accepted: 3 June 2021

Published: 8 June 2021

Publisher's Note: MDPI stays neutral with regard to jurisdictional claims in published maps and institutional affiliations.

Copyright: (c) 2021 by the authors. Licensee MDPI, Basel, Switzerland. This article is an open access article distributed under the terms and conditions of the Creative Commons Attribution (CC BY) license (https:// creativecommons.org/licenses/by/ $4.0 /)$.

\begin{abstract}
The psycho-didactic approach in education is becoming more and more popular. Its supporters emphasize the great values that are associated with the implementation of this approach to various fields of science and school subjects. The greatest value of the psycho-didactic approach is supporting the personal growth of the learner by respecting the developmental factors involved in each subject's learning processes. Psycho-didactics could also be used in the design of core curricula and their implementation in the field of religious, ethical, and moral education. By supporting personal development through moral and religious education, it is possible to simultaneously influence the agencyof each learner. Personal agency in self-development, as well as in religious and moral development, is one of the greatest challenges for modern education and one of the most significant issues of positive mental health advancement in the field of education. Within psycho-didactics, it becomes possible to foster every student in an individual way, therefore all methods and techniques used in the psycho-didactic approach are focused on the student's needs.
\end{abstract}

Keywords: psycho-didactics; religious education; moral education; moral development; positive mental health; healthy person

\section{Introduction}

This paper focuses mainly on the meeting point between educational psychology and the didactics of religion and ethics in order to establish a new quality of moral education for adolescents and adults. Nowadays, education must not only serve to increase knowledge, but also provide stimulation of development in such a way as to shape a mentally stable individual who is capable of autonomous self-development, in-depth selfreflection, and self-realization. Supporting overall personal development is also supporting mental health. Therefore, an adequate educational approach is needed. In this context, the psycho-didactic approach seems to meet those expectations. The psycho-didactic approach in teaching is relatively new and, to date, very few studies have been done to show the effectiveness of it. It is defined as a boundary branch between didactics and educational psychology (Holubář and Hájková 1993). In this sense, psycho-didactics is a pedagogical approach in which psychological knowledge is used not only to organize but also to support the ongoing teaching and learning processes to the extent to which the process itself contributes to the personal growth of each student. Psycho-didactics, in general, aims to introduce a new quality of pedagogical outcomes, which combines psychological, didactic, methodological, and thematic knowledge into one, and which should also be treated as a completely new, innovative school and teaching environment, and technology, fostering the personal and cognitive development of students. It should create conditions for students' psychological augmentation on the basis of the improvement of the effectiveness of teaching in a specific subject (Kholodnaya and Gelfman 2017; Kholodnaya and Gelfman 2016). Therefore, teaching a given subject, e.g., mathematics, 
cannot focus solely on knowledge in this area, but must focus atthe same time on the awareness of various psychological processes that mediate learning. Many already-known effective strategies, methods, and techniques of the psycho-didactic approach have been introduced into the pedagogy of creativity in learning languages (Kamińska 2018) as well as the teaching of mathematics (Kholodnaya and Gelfman 2017), and physical education (Derbali et al. 2017). The psycho-didactic approach promotes, inter alia, the autonomy of the student, connecting learning with the individual learning needs, authenticity, learning by making mistakes (the so-called process of conceptualization) (Kamińska 2018). It seems that the interdisciplinary potential of psycho-didactics is its quintessential feature, which can also be used to create programs to support religious and moral education and, therefore, also contribute to overall personality development. Moreover, it seems that spirituality and morality are particularly important areas of personal development (Maslow 2014). There is also support for the relation between moral and religious reasoning (Conn 1981). It is possible that a high level of personal development is associated with a correspondingly high level of moral and spiritual development. Moreover, morality and religiosity are often closely related, although morality can be understood entirely secularly. Even then, it is not completely inconsistent with religious morality (e.g., Christian, Judaic, or Hindu morality) in terms of promoted values, standards, or rules of conduct. The psycho-didactic approach is strongly related to person-centered teaching (Rogers et al. 2014). As such, it appears to be the most relevant approach to organizing the didactic process in the field of moral and religious education.

The traditional system of teaching was based on a subject-centered approach. To establish how effective it was, the level of knowledge obtained by a student had to be measured accordingly for every school subject. While, in the case of most subjects taught at school, it works well, in the case of teaching religion or ethics it does not seem to be a very good solution. Religion or ethics lessons are not only about the level of knowledge. These are school subjects that are expected to shape specific attitudes, which are immeasurable. In this case, the subject-centered approach must therefore be replaced by something more adequate. The psycho-didactics approach has modified evaluating criteria into those changes in a student's own personality and cognitive skills which describe his or her development in terms of productiveness, self-sufficiency, activity, and creativity. This may also contribute to student's mental health, defined in a positive way (Jahoda 1958; Tengland 2001). What is more, mental health translates into the development potential of an individual. It may be defined, for example, by personal growth initiative, which is explained by the individual's active and intrinsically motivated need to grow in those areas which are personally important (Beri and Jain 2016). This, in turn, is only fully realized when favorable conditions are provided. In the case of a school, the conditions will certainly depend on the approach to organizing the teaching process. In this regard, the teaching process can be improved with a psycho-didactic approach. The psychodidactic approach should be understood mainly as a branch of pedagogy, but with its basis in interdisciplinarity, as has been stated previously. Psycho-didactics combines and integrates psychological methods as well as didactic, methodological, and specific thematic knowledge. The prefix 'psycho' strongly underlines the role of psychological processes in defining the aim of this approach. Therefore, in the psycho-didactic approach, there is one main aim: to organize the teaching process and educational environment to the extent that it will foster the personal development of each student. It should create the best space for the student's psychological growth according to improved teaching effectiveness in a specific school subject and in overall understanding. It is also seen as mental health prophylaxis in terms of providing tools to protect the student from psychological trauma. One of the ways to ensure psychological safety is to take care of the self-determination and agency of students (Ryan and Deci 2006). As a result, they feel their influence on the education process, and therefore do not feel overwhelmed by the education system. Apsycho-didactic approach, in which attention is paid to the mental well-being of the student, plays a supporting role in itself. When we add to that also the psychological 
knowledge related to effective methods of satisfying the cognitive and emotional needs of the student, we will be able not only to teach but also to educate in a much wider scope.This may result not only in increasing the level of knowledge and skills in a given field but also in the overall stabilization of mental functioning. We know that this is a necessary condition for self-development (Neff 2011). One of the possible criteria of positively understood mental health is acceptance of oneself, growth and development, or personal integration and autonomy (Jahoda 1958).Mental health and personal growth can be also catalyzed by moral and spiritual growth (Weber and Pargament 2014).

This paper aims to show that it is also possible to implement the methods of the psycho-didactic approach to support individual spiritual and moral development in the course of the education of ethics and religion, understood as a specific school subject. Emphasis will also be placed on the importance of psychology and psychological methods fostering moral and spiritual development as an important aspect of upbringing processes in religious and moral education. There are no publications or studies linking the assumptions of the psycho-didactic approach with teaching in the field of religious and moral education, fostering of religious development, or of moral competence in the realm of positive mental health. This paper aims to fill this gap in terms of introducing the possibilities of implementing psycho-didactics into practice. The justification for emphasizing the special importance of the psycho-didactic approach in teaching religion and ethics, and stimulating spiritual and moral development, is assumed by the subject itself. Educational programs which stimulate religious and moral development are in line with the assumptions of the psycho-didactic approach. Their main goal is-as in psycho-didacticsthe personal development of an individual as an autonomous agent, but in a spiritual or moral context. Religious and moral growth seems to emerge directly from personal autonomy (Ebstyne King 2003). From the perspective of the psychology of religion, it is possible to find assumptions that religion is one of the most important needs coming out of the process of emergence of the autonomous personality (Roehlkepartain et al. 2006; Benson and Roehlkepartain 2008). Maslow (1970) argued that self-actualization is accompanied by mystical, religious experience. Allport (1978) considered autonomy to be a direct consequence of mature religiosity. Even Kohlberg assumed that the highest stage of development of moral reasoning is closely related to the personal development and spiritual commitment of the individual (Kohlberg and Power 1981). In all cases, religious development is parallel to personal development and moral development (Prest et al. 1999). A relationship with the Supreme Being does not mean dependency upon it that might not be possible to put together with the need for autonomy, and personal and developmental independence. What is more, one can assume that building a mature relationship with the Supreme Being requires developmental autonomy and the intrinsic need for such a union (Ellison and Sherkat 1993). All of this can contribute to maintaining mental stability. It can serve as an important factor in protecting against negative outcomes for the mental health of individuals. This is especially important in today's demanding times, and in the face of numerous studies showing the early occurrence of specific mental problems. High school and university students are particularly vulnerable and prone to mental disorders (Brown 2018). The psycho-didactic approach may, in this case, play an important preventive role and, at the same time, be a response to the important developmental needs of students.

\section{Psycho-Didactic Approach to Education: Background and New Possibilities}

The background for the consideration of psycho-didactics should be described within the subject-centered approach, as the previous widely popular paradigm of teaching and learning. The subject-centered approach is the most traditional concept of the curriculum, and is therefore the most commonly used approach in the organization of educational experiences (Ornstein and Hunkins 1993). As has already been mentioned, the subject-centered approach states the meaning of specific knowledge in every school subject and defines the development of a student in terms of the results of the measurement of theirprogress in 
gaining this knowledge. In the subject-centered approach, the textbook contains all of the guidelines for the implementation of the curriculum. At the same time, it can be considered as the manual for the teacher, composed of the main parts of the material, examples, exercises, and summaries. In this approach, the textbooks for all school subjects are built in this way. The distinction between the curricula of the different school subjects has its practical aspect, but also causes limitations in the overall educational processes. Finding contact points between different areas of the knowledge, thinking synthetically, finding mutual references across disciplines-these are examples of the abilities, the acquisition of which guarantees educational success. However, at the same time, this acquisition causes problems that the students and teachers must manage within the subject-centered approach. Most of the problems are based on a strictly defined curriculum included in the manual for each subject on a separate basis (Deng 2017). Meeting points and interdisciplinarity are beyond the area of interest of the subject-centered approach. Learners and teachers must find their own way to cope with difficulties, and to meet the requirements of the modern education system and the modern world at once. Of course, there are many different faces of the subject-centered approach;for example, the idea of a subject understood as ' $a$ being' included in the relationship between the teachers and the learners (Palmer 2017). This changes the perspective from learning a certain subject into engagement in this subject somehow personally. In this case, one may rather think of a complex matrix of relationships not only between the teachers and students, but also between the subjects which are seen as vivid and present, and not only passive and subordinate. It implies an assumption about the engagement of both the teacher and the student. Therefore, this can be interpreted as an example of a combination of the subject-centered approach with both the teacher-and learner-centered approach. From this point, another step is psycho-didactics as a new paradigm, not only in the organization of curricula and the didactic process, but also in providing support for personal development and maintaining the positive mental health of students. This aspect must be taken into account while discussing the direction of changes in modern education (Winzer et al. 2018). Students' self-development and their positive mental health are becoming equivalent goals in the process of designing significant educational changes (Breslau et al. 2008). This can be clearly seen in the context of moral and religious education.

What psycho-didactics has to offer as the new approach to education is the emphasis on the role of self-determination in the process of shaping the personality of an individual within the realm of education, as well as an autonomy-supportive teaching context (Ryan and Deci 2000; Reeve and Cheon 2021). Many authors who sympathize with the psycho-didactic approach underline the importance of psychological processes such as motivational processes or the need for self-regulation as the main driving forces of all learning processes (Ryan and Deci 2006; Niemiec and Ryan 2009). In the face of this, education is seen not only as a process of knowledge transfer and evaluation of its' effects, but also as a process of supporting the personal growth of an individual. The intrinsic motivation and social development of a learner during the education period can influence their sense of well-being (Ryan and Deci 2000). In the innovative psycho-didactic approach, every educational goal must serve the individual's personal and social fulfillment, not only the fulfillment of the curriculum requirements (Wildová 2015). It has a lot do with psychological, moral, and religious growth in terms of providing positive mental health support for each developing individual (Bewick et al. 2010).

\subsection{Student and the Possibilities and Demands of Psycho-Didactic Approach}

The psycho-didactic approach should be regarded as being opposed to the dominant model which is based exclusively on the cognitive support of the student (Russell 2009). As such, it can be understood as being part of the anti-cognitivist movement in education (Simpson and Beckett 2014). The psycho-didactic approach is strongly focused on the meaning of affective factors in the learning processes. As such, they are also involved in the process of individual development. Emphasizing affective properties in the process of 
acquiring knowledge (e.g., fostering motivational processes), as well as in the process of personal growth (e.g., shaping the agency), makes the psycho-didactic approach one of the best suited educational approaches. The affective aspect of teaching and learning is also crucial for building a professional relationship between the teacher and the student. It also provides protection against stressful events and their negative psychological consequences (Conley et al. 2017). Such a relationship is of the highest importance in the context of the acquisition ofthe abilities and skills needed to proceed with the knowledge in real-life settings, such as dealing with problems or being able to participate in discussions with others. It is especially useful for ethical dilemma discussions involving religious beliefs and moral attitudes, such as discussions considering the problem of modern reproductive choices (Khan and Konje 2019). From this point of view, Selman's theory of role-taking, based on the ability to understand the perspective of a third party, describes to what extent reflexivity and consciousness could be implemented into the process of creating a favorable learning environment in order to foster social-cognitive understanding (Selman 1976). This means that the student who understands the teacher's perspective and the teacher who understands the student's perspective may help each other in the process of achieving the educational goals of both sides. It is crucial to take into consideration that social-cognitive understanding is therefore deeply grounded in affective abilities, e.g., emotional empathy (Cuff et al. 2016). Simply understanding another's point of view is not enough to empower social development based on mutual interactions. It must include active participation in social cooperation;awillingness to act or to make contributions for the sake of other people (Reiman 2000). Here, the psycho-didactic approach comes with the very beneficial idea of combining affective and cognitive factors in the realm of education. Affectively driven decisions about how and when to use the knowledge, and for what purpose, are of the same importance as the knowledge itself. This is why psycho-didactics strengthen students' personal learning styles as a support of the individual developmental processes (Cerna 2018). In the context of all of this, a religious education based on supporting one's own spiritual needs, rather than indoctrination, would be most desirable. Similarly, with moral education, it is not about shaping a specific type of morality, but about the individual moral growth of a person striving for their individual moral autonomy.

\subsection{Teacher and the Possibilities and Demands of Psycho-Didactic Approach}

Individualization and empowering agency in education, with an emphasis on supporting affective-cognitive development, is mandatory in the psycho-didactic approach. At the same time, it is important in the process of introducing an advantageous and safe learning environment in which the teacher becomes the facilitator of the student's personal growth. A safe learning environment must be based on mutual support and respectful communication between the teachers and the students (Clapper 2010). To achieve this goal, psychological knowledge, as well as psychological methods, should be used by the teachers (Nussbaum and Dweck 2008). It is important for a teacher to know to what extent grading and assessing can influence the individual student's self-esteem. Simply calling one smart or not may have an influence on this person's self-evaluation and further performance. Some students cannot deal with this and become uncertain or avoidant towards any assessment situation (Dweck 2007). At the same time, they may become more sensitive to criticism, which can lead to hiding mistakes rather than correcting them (Mueller and Dweck 1998). Another threat is the learned helplessness phenomenon, where individuals believe that their own performance has no influence on the ongoing situation that they are involved in (Seligman 1992). The outcome of this is undermined motivation and productivity loss, as well as anxiety and depressive disorders (Andrews and Wilding 2004). Students who are often exposed to situations of educational failure are more at risk of the development of learned helplessness as a generalized response (Sutherland et al. 2004). Changing this state of mind must be based on critical reflection, a trustful environment, and an atmosphere of safety, especially when it comes to religion or morality. Only then can students make mistakes in order to learn from them, without 
being terrified about negative outcomes and painful consequences. Therefore, meaningful contextualized assessment, and a competency-based curriculum and methodology, should be introduced (Sarivan 2011). It improves the reflexivity of the teacher, who is not only the facilitator of the student's educational and personal growth but also an important source of social support. As it is shown in research, positive social support can have a very positive impact on student wellbeing. A significant lack of social support can determine many mental health problems (Alsubaie et al. 2019). It is a necessity of the psycho-didactic approach to have a positive impact on the students through self-conscious and reflective teachers who know how different psychological processes may influence the development of the student. Such specific areas as religious and moral education are especially in the need of the psycho-didactic approach, since the content of the curriculum of religion or ethics courses at school is highly sensitive and not neutral. It is already established that there is a strong link between morality, religion, and mental health (Dein et al. 2010). Therefore, it should be taken into account in the realm of education. A teacher representing a psychodidactic approach, based on the available psychological knowledge, should design didactic interactions in such a way as to maximize developmental opportunities and minimize threats to the mental health of each student.

\section{Psycho-Didactic Approach to Religious and Moral Education}

One of the most important aspects of overall human development and well-being is moral and spiritual growth (Moreira-Almeida et al. 2006). Many leading theories of personality development point to the role of morality and religion as one of the most important aspects of the psychosocial functioning of a person (Maslow 1970; Allport 1978; Erikson 1993; Maslow 2014). The process of shaping one's morality starts with the family environment, but the school strengthens the power of influence of the family of origin in this respect as well as individual changes in the emerging autonomy of the developing person. The same is true of religion, which sometimes strongly shapes individual morality, although this relationship is most often bidirectional or does not exist at all. Within the realm of school education, moral and religious development is influenced by the stability of participation in the classes, the methodology used by the teachers, and the topics raised. Moral and religious education refers to the broader context of character education. It turns out that in both spheres of character education, the clarification of moral or spiritual values is definitely not enough (Lockwood 1978). Practical application and reference to the realities of everyday life are important (Balakrishnan 2011). Cultural differences, as well as religious plurality and diversity, cannot be overlooked (Klutz and Lakmaier 2016). The safe and positive atmosphere of the school plays a crucial role here, especially when it comes to providing religious and moral tolerance and respect. Philosophy and ethics classes that promote prosocial and altruistic attitudes, as well as the values of justice, responsibility, and truthfulness, support moral development strongly and visibly (King and Mayhew 2002). Moral development can be mediated by spiritual growth and personal religious involvement (De Souza 2006). What is more, autonomous individual spirituality positively influences social behavior. The same is true of autonomous individual morality. In this case, we also expect a translation into social development and a high level of social functioning. It can also be applied to the process of shaping deeper relationships in a peer group, and then in an adult social life. The religious context can promote a sense of identity which transcends the self towards the social good (Ebstyne King 2003; Regnerus et al. 2004; Collins-Mayo and Dandelion 2010). The teacher's own attitudes, religious involvement, and morality are also significant for the process of fostering student's development, but only if the teacher is open to discussion and willing to accept other points of view. It seems that the more willing the teacher is to discuss, the more the value of justice, care, righteousness, or religiousness is applied in their behavior in the teacher-student relationship (Oser 1994). It is not enough to transfer religious and moral knowledge exclusively. Without leaving enough space for student's self-evaluation during participation in real-life scenarios, or at least semi-real situations, the teacher will 
not succeed. The person who is about to shape their own morals or own beliefs must be able to internalize them within their own personal change. Therefore, religious and moral education is of a very special kind. It touches not only the cognitive surface in terms of a change in the amount of knowledge possessed but, at the same time, emotional involvement in the quality of it and evaluation of it within the framework of practical implementation. It also implies the ability to discuss and question one's own knowledge and attitudes in order to be able to change them if necessary. That would not be possible without openness to such experience, as well as without tolerance and trust. Religious and moral education is not neutral (De Souza 2006). Due to the fact that moral and religious education is not neutral, it is exposed to extremism and intolerance towards otherness. The psycho-didactic approach, in respecting the psychological knowledge about human beings and their social life, presupposes unequivocal opposition to such attitudes. It must take into account a whole range of responsibilities. One of the most important is that it aspires to trigger a change in a single person in one direction: towards becoming better, but not at the cost of humiliating anyone else or unjustified self-exaltation. To do that with the best quality possible, methodological awareness, as well as the teacher's correct attitude, is simply a must. Ethical and religious education should not be carried out only with classical delivery methods which are not suitable for the individual understood as an agent (Bandura 2001). The significant role of practical solutions should be implemented as well. Where the practice plays the most significant role, it is worth considering if the psychodidactic approach can meet the requirements of the most effective moral and religious education paradigm. It has already been shown that mixed methods used in an educational context increase the complexity of ethical and moral decision-making, therefore putting moral education closer to real-life scenarios, making it more effective (Preissle et al. 2015). It also applies to religious education, which should be centered on individual spiritual needs. Such an approach should avoid dogmatism and imposing unambiguous attitudes. Instead, the emphasis should be on leaving as much space as possible for the exploration of our own, autonomous religiosity, regardless of what specific religious culture someone comes from. This is in accordance with psycho-didactics, which have never been used specifically in fostering religious and moral development. Despite the fact that the psycho-didactic approach to education is novel in the field of religious and moral education, there already are some methods and theories used in the realm of moral and religious education that could be treated as 'psycho-didactic-like', even if their introduction was not based directly on this paradigm. The basis for qualifying these methods as to some extent psycho-didactic is the impact they have not only on the knowledge of, but also the personal change in, learners. What is more, all of these methods are based on psychology, and psychological methodology and practice. Therefore, they can be used as psychological tools providing support to maintain positive mental health.

The very first example for moral education could be Lawrence Kohlberg's Just Community Approach (Kohlberg 1985), which is based on John Dewey's idea of putting autonomy, responsibility, democracy, and education into one process of promoting the democratic and moral competencies of school students (Dewey 1997). In this approach, students are equally engaged in democratic decision-making within the school management. Students attend discussion meetings in order to put democratic rules into the practice of making their own choices. They make joint democratic decisions on issues related to school life regarding equality, equity, and reciprocity (Higgins 1995). The Just Community Approach, as an example of implementation of the psycho-didactic paradigm, has been proven to be effective in terms of fostering moral-democratic development. To mention some effects, the positive moral atmosphere created by introducing the Just Community Approach into the school environment can foster responsibility of the learners (Higgins et al. 1984), as well as their engagement inthe promotion of justice, peace, and tolerance (Power 2013). These are not only behavioral, but also personal, changes. The feeling of being responsible is deeply rooted in the attitude of care and awareness of specific values to be engaged with. Training someone in order to make them responsible will not bring the expected results unless there 
is a change in the person themself. Responsibility is a matter of care and being aware that the object of care and protection is valuable, which means no less than that it represents values and/or virtues that should be somehow protected. Only making students feel this way, personally responsible, makes them act in a responsible way.

Another promising 'psycho-didactic-like' method for moral education is the original Konstanz Method of Dilemma Discussion $\left(\mathrm{KMDD}^{\circledR}\right.$ ) by Georg Lind.TheKMDD ${ }^{\circledR}$ aims to foster moral competence and promote deliberation and discussion instead of violence, deceit, and fobbing the responsibility off onto others (Lind 2016). Moral competence is directly associated with individual behavior (e.g., decision making) when facing a moral dilemma experience and can be defined as the ability to judge arguments according to their intrinsic value, no matter if they are arguments in favor of one's own opinion. A highly moral, competent person would always pay attention to whether the argument of the opposition side is of high quality, not only if it is one that strengthens their own line of argumentation. It is a matter of acceptance and openness. Georg Lind's idea originates from Lawrence Kohlberg's theory, according to which cognitive development is to be regarded as a prerequisite of overall moral development (Kohlberg 1985). At some points, Kohlberg's theory ignores the complexity of moral development by reducing it to the meaning of cognitive aspects. This theory cannot be used as a sufficient basis for educational practice supporting general developmental capabilities, including moral development as well as personal moral growth. The ability to build moral reasoning is not the same aspersonal morality. Therefore, fostering moral competence which is used in dilemma situations requires more than the stimulation of cognitive development. Based on this, Georg Lind from the University of Konstanz introduced the dual-aspect theory of morality and moral development and a new method to measure this construct-the Moral Competence Test $\left(\mathrm{MCT}^{\circledR}\right)$. The previously mentioned original method of fostering moral competence- the Konstanz Method of Dilemma-Discussion (KMDD $\left.{ }^{\circledR}\right)$-is a practical part of the dual aspect theory of morality and moral development (Lind 2008). It incorporates some of Kohlberg's postulates, but also makes the theory more coherent with empirical data (e.g., the regression of the level of moral competence when it is not actively fostered) (Lind et al. 2017). It claims that cognitive and affective elements are inseparable, although distinct. These two aspects should be maintained in parallel in the process of fostering the moral development of students in order to provide them with a democratic way of living in which we not only think morally but also act morally (Lind 2016). KMDD ${ }^{\circledR}$ is based on discussing semi-real moral dilemmas according to democratic rules and guidelines. Participants who are engaged in the discussion are divided into two groups and exchange arguments in a peaceful manner without evaluating persons from the opposition group and without showing any disrespect to those who are speaking at each moment. In KMDD ${ }^{\circledR}$, there is also a phase in which all participants choose the best argument or several arguments from the opposition group. During this phase, students learn that even if their opinion is different, they can still respect their opponent for the quality of arguments stated by them. It reduces the conflicted attitude and helps them to understand that we do not need to be in perfect agreement with other people's opinions to cooperate and help each other if there is such a necessity. It is the very beginning of democracy, and democracy is making morals closer to social life. The best way of supporting moral development in all aspects has to be grounded in providing situations in which students will find themselves respected members of classroom democratic society. Drama lessons should also be introduced to strengthen the impact on moral development by giving an opportunity to take in other people's perspectives (Dowdy and Kaplan 2011). Such methods must always be embedded in positive emotions, mutual respect, and empathy. Most of the research and educational programs are aimed at stimulating development mainly with regard to reasoning (Schremer 1992). It is not entirely enough to fulfill the personal growth of a single person, who is always complex and irreducible. Therefore, the personal approach must also be holistic, just like the psycho-didactic approach itself. 
An example of a method of teaching religion based on psycho-didactic assumptions is the approach that combines religion with the analysis of literature (Boscaljon and Levinovitz 2019). Once again, it is not a psycho-didactic method by definition but through the solutions it proposes. It is an interdisciplinary approach that uses a variety of ways to connect literary threads with the religious context or vice versa. A student may relate to different religions, but also to different aspects of a given religion. Literary themes can make it easier to navigate in the abstract area of spirituality. Numerous analogies may allow for finding similarities, for example, between the described dilemmas of the hero of a given novel and one's own search for answers to questions about the meaning of life or ultimate matters. It is a method that, first of all, does not impose ready-made solutions, thus leaving room for the individual's own exploration. This is especially important in such a sensitive area as individual spirituality. Thanks to this, a sense of control and self-determination is supported which contributes to personal autonomy.

The Forum Theatre is another 'psycho-didactic-like' method that can be introduced to moral education as well religious education (Thambu and Rahman 2017). It requires more engagement from the organizational side, but also brings educative scenarios connected with social and moral life into practice through the implementation of theatrical intervention. Theatre in education, in general, could be considered to be a tool of change in the behavior, also in moral and social actions, as it creates a space not only for role-taking but for going through important experiences. Making it possible to become a part of a play, to feel the impact one has on the whole group, is still something that strongly influences the person. Forum Theatre is a type of the Theatre of the Oppressed (TO), introduced originally by Augusto Boal. It is based on the idea of learning through critical and reflective thinking as well as emotional engagement ina social situation (Boal et al. 2019). Forum Theatre is a participatory theatre that makes it possible to be part of the play even if one is a spectator. This is why Boal called spectators of Forum Theatre performance spect-actors-the people who not only see the play but also act in the play to the extent to which they can influence the plot and the actors' performance in order to change the expected result. The actors present a scene and the spect-actors (the audience) help change the outcome by proposing changes in the behavior of the protagonists. The actors are required to maintain the proposed change in the behavior of their character in the scene. This may lead to key changes in the presented story. Participants are confronted with a play that shows some kind of social problem which is vivid among them, which additionally triggers reflection and emotional insight (Schutzman and Cohen-Cruz 1994). The ability to change the situation within the play helps the spect-actors to understand that, in real life, they can also influence the course of events. Forum Theatre addresses social, political, and economic issues (e.g., religion, racism, poverty, homelessness, violence, sexual harassment, religious conflicts) (Thambu and Rahman 2017). At the same time, it fights back by fostering democratic and cooperative forms of interaction among people in order to solve the problem. It uses dialogue and community-centered problem solving to show how to deal with oppression in daily life (Levy 1997). This can be considered very close to the concept of moral competence, therefore it is also teachable (Lickona 1996). Teaching this kind of ability influences the process of shaping the student's personality. Shaping specific competencies enriches the repertoire of behaviors and feelings, which builds the individual's personal standard. This is a serious argument for the possibility of treating such an approach as psycho-didactics in the field of moral education and religious education.

These are just examples of well-known and already widely-evaluated psychological methods and approaches to teaching religion, morality, and supporting the overall development of an individual. There are many others, just to mentionafew: Sustained Dialogue (Saunders 2001), conflict management (French and Allbright 1998), problem-solving activities (Fins et al. 1997), role-taking (Selman 1971), fostering empathy (Hoffman 1991) \& altruism (Eisenberg and Miller 1987), social interaction (Gibbs 1987), and self-control abilities (Berkowitz 1982). All of these methods could be used in moral and religious education within the framework of the psycho-didactic approach. What is more, in moral and reli- 
gious education there is a strong need for innovation (Schreiner 2014). The psycho-didactic approach seems to meet this condition with an excess.

One more method must be emphasized here as important, not for fostering the development of a student directly, but that of the teacher themself. It is crucial for establishing the high quality of the teacher's attitude and work, which has a secondary effect on the student's moral and religious development. This is why the meaning of good psychological teachers' education is also on the spot in the psycho-didactic approach. The highly praised method here is Deweyan-based guided reflection (Husu et al. 2008). It helps to develop pedagogical and psychological practices in the education of teachers so that they can construct professional agency, which is needed in order to support the student's agency development (Leijen et al. 2014). The teacher is not only the "knowledge giver", but also a tutor, a facilitator, andsomeone who knows the learner to such an extent that they can choose appropriate psychological methods to provoke a personal change in their sense of personal growth and development. The psychological education of teachers should be considered to be a very important aspect of the psycho-didactic approach. Only a reflective teacher, aware of developmental processes and the impact of different educational factors on individual development, will be able to plan and implement educational interventions that would actually have a positive impact on the learner's personal growth. Even managerial competencies seem to have an influence on the educational processes organization and self-evaluation of the teacher. This may lead to an increase in the quality of strategies introduced in order to develop critical and creative thinking (Duchovičová and Tomšik 2018). This is also a factor that strongly influences the personal change in the learner. The more critical and creative in thinking the teacher is, the more reflective the student becomes. The teacher's positive authority influences the learner's development. Therefore, the psycho-didactic approach should have a visible emphasis on the psychological education of teachers.

\section{Psycho-Didactics for Moral Identity Development-A New Strategy for Moraland Religious Education}

The psycho-didactic approach to education aims to foster the personal growth of the learner in terms of individual psychological development. In the field of religious and moral education, growth and-what is more-personal growth, is expected. On the one hand, religious and moral education should be based on the most neutral worldview and, on the other hand, it must meet the expectations that it will support development in a positive direction (towards something better, more appropriate, or expected). The idea of neutrality in education is strongly desirable and approachable, at least to the extent to which fairness and tolerance are educational goals (Kleinig 1976). In this context, it remains a contentious issue to what degree psycho-didactics meets the criterion of neutrality in the field of education and whether it's even possible, and more importantly-necessary. Everyone would agree that teaching that tolerance is not good is itself wrong. Therefore, teaching that tolerance is good may never be considered neutral. Regardless of the idea of neutrality, there is general agreement in education about certain issues related to a specific order of things. It can be assumed that there are fundamental issues on which, despite cultural and religious differences, people are willing to agree. Therefore, the psycho-didactic approach does not have to be afraid of conflict with the idea of neutrality in education. It is difficult to agree that individual development and personal growth are undesirable or bad. Everyone has a natural need for development and self-actualization (Maslow 1943). Not feeling such needs is a departure from what may be called positive mental health (Jahoda 1958). Although it would be too strong to consider psycho-didactics as a form of therapy or psychological help, this approach can certainly have preventive significance, such as proposing appropriate behavior patterns or creating a safe learning environment. In this regard, the psycho-didactic approach can foster the moral and spiritual growth of a learner. Such growth can be operationalized as the process of increasing the coherence between thinking, emotions, and acts, or the consistency between one's own internal standard and its externalization in real situations. This leads to the concept of 
moral identity (Narvaez and Lapsley 2009a) and religious identity (Arweck and Nesbitt 2010). Both of them serve to maintain a coherent image of oneself as a moral and/or religious person. This can have a significant impact on building self-esteem and personal agency. Therefore, the psycho-didactic approach to moral education struggles with the question of the most adequate moral and religious identity and character education (Blasi 2005). It must refer to individual identity, which must be protected from harm, especially among children and adolescents for whom keeping their sense of being a person of a certain kind is highly important. As it has been shown in research, religious adolescents reported not only prejudice and criticism of their beliefs but also a distortion of their religious traditions. Such behaviors were represented not only by their peers but were sometimes also experienced directly by their teachers (Moulin 2015). The same is probably true of personal morality. If the psycho-didactic approach is to be considered as capable of inducing a personal change in the learner, emphasis should be put on the responsibility and competence of the teacher who works in this approach, as well as on the quality of the psycho-didactic procedures, methods, and techniques. The teacher must be aware of the possibility of molding another person's attitudes, especially in the field of spirituality and morality. This also shapes one's self as an agent and the feeling of being a person of a certain kind, e.g., moral person, who desires to be a good or religious person, or who desires to submit to something supernatural.

Researchers from the field of developmental psychology also pose a question regarding the moral and/or religious identity problem. Here, another question arises: to what extent can moral/religious identity be an aspect of identity in general, and what is its role in the personal and psycho-social development of the individual. The problem of the significance of those two aspects of identity for understanding the relationship between reasoning, emotions, and actual behavior is also considered. The theoretical construct of moral/religious identity is still not very well known, but it evokes the reasoned interest of researchers and the legitimate interest of theoreticians of education. It is widely argued whether, for example, moral identity can be described in terms of its centrality for the overall identity and personality development (Narvaez and Lapsley 2009b). In such a case, moral identity must be taken as something of great consistency in respect of one's life. Moral identity is regarded here as the central positioning of everything that constitutes a moral category in relation to all other categories that order the understanding of individuals and their world (e.g., cognitive schemas). The same will contribute to religious identity. In the realm of education, identity (also moral and religious identity) should be considered to be a dynamic system consisting of many parts, in which one can distinguish elements of self-knowledge, organizing the processing of information about oneself (Lester 1993). Dan P. McAdams (McAdams 1996), referring to the original William James concept of the continuity of the stream of consciousness (James 1913) as an important component of identity, mentions selfing, which should be understood as experiences which belong to the experiencing subject, largely constituting that subject. This translates into a sense of stability, continuity, autonomy, and control over the course of events (McAdams 1995). It corresponds with the stability of commitments to self-standards, personal goals and values, and beliefs (Berzonsky and Neimeyer 1994). One of the most important areas of commitment is the scope of the value system that the individual chooses during development. Stable identity, and religious and moral values, in turn, are the foundation of the processes of giving meaning to experiences, which are dynamic but lasting in time (Reker and Chamberlain 2000). These are also the foundations of positive mental health, which allows individuals to realize their full life potential and well-being. It can also contribute to self-regulated proactive coping (Aspinwall and Taylor 1997), optimism, and overall life satisfaction (Usán Supervía et al. 2020).

What is more, research shows that, in defining oneself, moral categories turn out to be more accessible than competence-related features (Wojciszke et al. 1998). The individual need to consider oneself in moral terms is key to accepting oneself and one's place in the social world. Many morality scholars clearly recognize the need to find a connection between those aspects (Kingsford et al. 2018; Jennings et al. 2015; Lapsley 2015; Narvaez 
and Lapsley 2009b). One of the suggestions is the hypothesis about the existence of moral identity. This will also apply to religious identity. This concept is associated with the answer to the question about the degree of compliance of moral/religious thinking and feeling, and the undertaken action itself. The motivation behind the involvement in this issue is the assumption that a high level of moral reasoning does not logically indicate morally correct behavior, as well as religious thinking does not necessarily lead to the desired way of conduct. One's behavior in a given situation is determined by the degree to which judgments are integrated with the identity and the extent to which the identity is coherently shaped around central moral or religious categories. The desire to remain for oneself a person of a certain kind will therefore be an important motivator of actual actions, e.g., morally good actions (Blasi 1984). Moral and/or religious identity can be understood as giving special significance to moral categories in the process of defining oneself as a person of a particular kind ('I am a moral/religiousperson'). Thus, one can speak of defining identity through the prism of the centrality of categories in dynamic self-recognition. In understanding oneself as a moral individual, it can also be expected that a clear sense of commitment to ethical goodness will appear in the behavior (Narvaez and Lapsley 2009a). Religious identity also plays a significant role here. Commitment to a certain type of religiosity, as well as engagement into specific beliefs, seems to play a significant role in becoming adult and autonomous. During emerging adulthood, religious identity generally remains stable over time despite a possible decline due to social reasons which appear rather temporarily (Uecker et al. 2007). It shows how important it is for young people to feel constant religious engagement during the process of transition to real adulthood (Barry and Nelson 2005). Religiosity plays a significant spiritual and social role in the lives of adolescents and their psychological well-being (Davis and Kiang 2016). It is worth mentioning that religion can be an important aspect of morality, but morality and religion can also exist independently as religion, of which morality is an inalienable part, or secular morality unrelated to any religious context. Either way, for many young people, being religious is considered as being moral. In many religions, certain moral attitudes derive directly from religious doctrine (e.g., Christian morality). In such cases, religion becomes the justification and foundation for a certain type of morality (Sutton and Schmidly 2016). Religious and moral identity seem to be very close to each other. Therefore, moral and religious education must cooperate and create the most relevant background for fostering personal growth with regard to the moral and spiritual needs of each developing individual.

From the point of view of moral and religious education, this is something to be expected and which is highly desirable as an effect of educational interventions. The psycho-didactic approach seems to be the answer to those needs and expectations. It brings some new ideas regarding putting psychological techniques and knowledge into the new pedagogical and didactic context in order to improve the personal moral and religious growth of the learner.

\section{Discussion}

The idea of using psychological methods in the process of fostering development within the field of education is not new in general and has a great theoretical background.However, the psycho-didactic approach in the context of religious and moral education is purely an innovative idea. The originality of the idea is based on its interdisciplinary potential and the new way of defining the aim of religious and moral education as fostering personal growth and psychological well-being. The unification of terminology, methods, and effectiveness of assessment are to be established in further research into this topic due to the fact of the objective need of putting the idea of psycho-didactics into practice. To fulfill and implement this plan, numerous studies will need to be carried out. This should help to establish to what extent the psycho-didactic approach can be used to strengthen the effectiveness of religious and moral education, and what kind of relationship can be found between education and individual religious, moral, and personal development. It also shows how important it is to pay attention to the individual, 
the personal position of the learner, and how significant the role of the teacher is in this regard. In the psycho-didactic approach, there is no space for establishing whether the teacher dominates the student or vice versa. Both of them are of the same importance. The only difference is in the level of responsibility taken. Here, the teacher or the educator is the one who is responsible for the learner's progress. In fact, the quality of this progress should be treated as the aim for a teacher who implements the psycho-didactic idea. The psycho-didactic approach to education is more than just another approach. It is one of the most demanding, but also most promising, approaches in education, especially needed in the realm of religious and moral education. It works vividly, for example, in the context of the education of creativity or shaping individual skills. However, it is not widely used in moral and religious education, where it would probably work best because of the strong inclination towards strengthening the personal growth of the learner and their positive mental health. Studies upon 'psycho-didactic-like' methods and techniques, as well as comparative studies, should be carried out to establish the effectiveness of the approach in practice. At the moment, there are many methods similar in their assumptions about the proposals of the psycho-didactic approach (psycho-didactic-like), but not created with regard to this approach. Admittedly, this shows how intuitive the psycho-didactic approach is. However, this is far too little. Now, methods are needed that are created at the beginning in accordance with the assumptions of psycho-didactics, methods with specific goals, precisely tailored to specific educational needs. Perhaps, at the same time, some methods could be adapted to the needs of the psycho-didactic approach. Regardless of the problems presented, the psycho-didactic approach is a promising prospect for education in general, and for moral and religious education in particular. Its' grounding in psychological and pedagogical foundations makes this approach one of the most independent, but also compatible with the development of the individual and the establishment of personal mental health. The possibility of using a psycho-didactic approach to religious and moral education is just one of the suggestions for possible use. The latest changes in education related to the Covid-19 pandemic have brought many different challenges which can be overcome by the psycho-didactic approach. One of them is the strong need for social reintegration and re-working of the psychological well-being of students. Nevertheless, the issue of supporting spiritual and moral development is still one of the most urgent needs in the area of improving education systems in order to increase the quality of the influences shaping future participants of modern democratic and tolerant societies.

Author Contributions: M.S. had the idea for the article and wrote the manuscript with support from M.M.K. who performed the literature search and critically revised the work. Both authors have approved the submitted version. Both authors agree to be personally accountable for the author's own contributions and for ensuring that questions related to the accuracy or integrity of any part of the work, even ones in which the author was not personally involved, are appropriately investigated, resolved, and documented in the literature. Both authors have read and agreed to the published version of the manuscript.

Funding: No funding was received to assist with the preparation of this manuscript. The authors have no relevant financial or non-financial interests to disclose.

Institutional Review Board Statement: Not applicable.

Informed Consent Statement: Theoretical content and review form of this paper precludes the approval board opinion and/or Informed Consent. No research has been carried out for this article in which human or non-human subjects participated.

Data Availability Statement: Not applicable.

Conflicts of Interest: The authors declare no conflict of interest. 


\section{References}

Allport, Gordon W. 1978. The Individual and His Religion: A Psychological Interpretation. London: Macmillan.

Alsubaie, Mohammad, Helen J. Stain, Lisa Amalia Denza Webster, and Ruth Wadman. 2019. The Role of Sources of Social Support on Depression and Quality of Life for University Students. International Journal of Adolescence and Youth 24: 484-96. [CrossRef]

Andrews, Bernice, and John M. Wilding. 2004. The Relation of Depression and Anxiety to Life-Stress and Achievement in Students. British Journal of Psychology 95: 509-21. [CrossRef]

Arweck, Elisabeth, and Eleanor Nesbitt. 2010. Young People's Identity Formation in Mixed-Faith Families: Continuity or Discontinuity of Religious Traditions? Journal of Contemporary Religion 25: 67-87. [CrossRef]

Aspinwall, Lisa G., and Shelley E. Taylor. 1997. A Stitch in Time: Self-Regulation and Proactive Coping. Psychological Bulletin 121: 417-36. [CrossRef] [PubMed]

Balakrishnan, Vishalache. 2011. Real-Life Dilemmas in Moral Education. Kuala Lumpur: University of Malaya Press.

Bandura, Albert. 2001. Social Cognitive Theory: An Agentic Perspective. Annual Review of Psychology 52: 1-26. [CrossRef] [PubMed]

Barry, Carolyn McNamara, and Larry J. Nelson. 2005. The Role of Religion in the Transition to Adulthood for Young Emerging Adults. Journal of Youth and Adolescence 34: 245-55. [CrossRef]

Benson, Peter L., and Eugene C. Roehlkepartain. 2008. Spiritual Development: A Missing Priority in Youth Development. New Directions for Youth Development 2008: 13-28. [CrossRef]

Beri, Nimisha, and Manisha Jain. 2016. Personal Growth Initiative among Undergraduate Students in Relation to Emotional Self-Efficacy and General Well-Being. Rupkatha Journal on Interdisciplinary Studies in Humanities 8: 43-55. [CrossRef]

Berkowitz, Marvin. 1982. Self-Control Development and Relation to Prosocial Behavior: A Response to Peterson. Merrill-Palmer Quarterly 28: 223-36.

Berzonsky, Michael D., and Greg J. Neimeyer. 1994. Ego Identity Status and Identity Processing Orientation: The Moderating Role of Commitment. Journal of Research in Personality 28: 425-35. [CrossRef]

Bewick, Bridgette, Gina Koutsopoulou, Jeremy Miles, Esther Slaa, and Michael Barkham. 2010. Changes in Undergraduate Students' Psychological Well-being as They Progress through University. Studies in Higher Education 35: 633-45. [CrossRef]

Blasi, Augusto. 1984. Moral Identity. Its Role in Moral Functioning. In Morality, Moral Behavior, and Moral Development. Edited by William M. Krtines and Jacob L. Gewirtz. New York: John Wiley \& Sons, pp. 128-39.

Blasi, Augusto. 2005. Moral Character: A Psychological Approach. In Character Psychology and Character Education. Notre Dame: University of Notre Dame Press, pp. 67-100.

Boal, Augusto, Charles A. McBride, Maria-Odilia Leal McBride, and Emily Fryer. 2019. Theatre of the Oppressed. London: Pluto Press.

Boscaljon, Daniel, and Alan Levinovitz. 2019. Teaching Religion and Literature. New York: Routledge.

Breslau, Joshua, Michael Lane, Nancy Sampson, and Ronald C. Kessler. 2008. Mental Disorders and Subsequent Educational Attainment in a US National Sample. Journal of Psychiatric Research 42: 708-16. [CrossRef]

Brown, June. 2018. Student Mental Health: Some Answers and More Questions. Journal of Mental Health 27: 193-96. [CrossRef] [PubMed]

Cerna, Miloslava. 2018. Psychodidactic Approach in the Development of Language Competences in University Students within Blended Learning. Open Learning: The Journal of Open, Distance and e-Learning 33: 142-54. [CrossRef]

Clapper, Timothy. 2010. Creating the Safe Learning Environment. Professional against Improperly LabelingActive Learners 3: 1-6.

Collins-Mayo, Sylvia, and Pink Dandelion. 2010. Religion and Youth. Burlington: Ashgate Pub. Ltd.

Conley, Colleen S., Jenna B. Shapiro, Alexandra C. Kirsch, and Joseph A. Durlak. 2017. A Meta-Analysis of Indicated Mental Health Prevention Programs for at-Risk Higher Education Students. Journal of Counseling Psychology 64: 121-40. [CrossRef] [PubMed]

Conn, Walter E. 1981. Morality, Religion, and Kohlberg's 'Stage 7'. International Philosophical Quarterly 21: 379-89. [CrossRef]

Cuff, Benjamin, Sarah J. Brown, Laura Taylor, and Douglas J. Howat. 2016. Empathy: A Review of the Concept. Emotion Review 8: 144-53. [CrossRef]

Davis, Richard F., III, and Lisa Kiang. 2016. Religious Identity, Religious Participation, and Psychological Well-Being in Asian American Adolescents. Journal of Youth and Adolescence 45: 532-46. [CrossRef]

De Souza, Marian, ed. 2006. International Handbook of the Religious, Moral and Spiritual Dimensions in Education. International Handbooks of Religion and Education. Dordrecht and London: Springer, vol. 1.

Dein, Simon, Christopher C. H. Cook, Andrew Powell, and Sarah Eagger. 2010. Religion, Spirituality and Mental Health. The Psychiatrist 34: 63-64. [CrossRef]

Deng, Zongyi. 2017. Rethinking Curriculum and Teaching. In Oxford Research Encyclopedia of Education. Edited by Zongyi Deng. Oxford: Oxford University Press. [CrossRef]

Derbali, Chawki, Ali Elloumi, and Fathi Matoussi. 2017. The Need to Learn According to Psycho-Didactic Approach: SelfDetermination and Student's Performance in Physical Education Realm. Creative Education 8: 1155-71. [CrossRef]

Dewey, John. 1997. Democracy and Education: An Introduction to the Philosophy of Education. New York: Free Press.

Dowdy, Joanne Kilgour, and Sarah Kaplan. 2011. Teaching Drama in the Classroom A Toolbox for Teachers. Rotterdam: Sense Publishers.

Duchovičová, Jana, and Robert Tomšik. 2018. Managerial Competencies of a Teacher in the Context of Learners' Critical Thinking Development: Exploratory Factor Analysis of a Research Tool and the Results of the Research. TEM Journal 7: 335-47.

Dweck, Carol. 2007. The Perils and Promises of Praise. Educational Leadership 65: 34-39. 
Ebstyne King, Pamela. 2003. Religion and Identity: The Role of Ideological, Social, and Spiritual Contexts. Applied Developmental Science 7: 197-204. [CrossRef]

Eisenberg, Nancy, and Paul Miller. 1987. The Relation of Empathy to Prosocial and Related Behaviors. Psychological Bulletin 101: 91-119. [CrossRef]

Ellison, Christopher G., and Darren E. Sherkat. 1993. Obedience and Autonomy: Religion and Parental Values Reconsidered. Journal for the Scientific Study of Religion 32: 313. [CrossRef]

Erikson, Erik H. 1993. Childhood and Society. New York: Norton.

Fins, Joseph J., Franklin G. Miller, and Matthew D. Bacchetta. 1997. Clinical Pragmatism: A Method of Moral Problem Solving. Kennedy Institute of Ethics Journal 7: 129-43. [CrossRef] [PubMed]

French, Warren, and David Allbright. 1998. Resolving a Moral Conflict through Discourse. Journal of Business Ethics 17: 177-94. [CrossRef]

Gibbs, John C. 1987. Social Processes in Delinquency: The Need to Facilitate Empathy as Well as Sociomoral Reasoning. In Moral Development through Social Interaction. New York: John Wiley \& Sons, pp. 301-21.

Higgins, Ann. 1995. Educating for Justice and Community: Lawrence Kohlberg's Vision of Moral Education. In Moral Development: An Introduction. Boston: Allyn \& Bacon, pp. 49-81.

Higgins, Ann, Clark Power, and Lawrence Kohlberg. 1984. The Relationship of Moral Atmosphere to Judgments of Responsibility. In Morality, Moral Behavior and Moral Development. New York: Wiley, pp. 74-106.

Hoffman, Martin L. 1991. Empathy, Social Cognition and Moral Action. In Handbook of Moral Behavior and Development. New York: Wiley, pp. 275-301.

Holubář, Zdeněk, and Eva Hájková. 1993. K Psychodidaktíce Školních Předmětů. Pedagogika: Časopis Pro Vědy o Vzdělávánía Výchově 43: 433-38.

Husu, Jukka, Auli Toom, and Sanna Patrikainen. 2008. Guided Reflection as a Means to Demonstrate and Develop Student Teachers' Reflective Competencies. Reflective Practice 9: 37-51. [CrossRef]

Jahoda, Marie. 1958. Current Concepts of Positive Mental Health. New York: Basic Books. [CrossRef]

James, William. 1913. The Principles of Psychology. New York: Henry Holt and Company. [CrossRef]

Jennings, Peter L., Marie S. Mitchell, and Sean T. Hannah. 2015. The Moral Self: A Review and Integration of the Literature: The moral self. Journal of Organizational Behavior 36: S104-S168. [CrossRef]

Kamińska, Aneta. 2018. The Strategies, Methods and Techniques of the Psychodidactics of Creativity in the Foreign Language Education of Young Learners. Edukacja Elementarna W Teorii I Praktyce 12. [CrossRef]

Khan, Mohammad A. Z., and Justin C. Konje. 2019. Ethical and Religious Dilemmas of Modern Reproductive Choices and the Islamic Perspective. European Journal of Obstetrics \& Gynecology and Reproductive Biology 232: 5-9. [CrossRef]

Kholodnaya, Marina A., and Emanuila G. Gelfman. 2016. Development-Focused Educational Texts as a Basis for Learners' Intellectual Development in Studying Mathematics (DET Technology). Psychology in Russia: State of the Art 9: 24-37. [CrossRef]

Kholodnaya, Marina, and Emanuila G. Gelfman. 2017. School Textbooks as a Medium for the Intellectual Development of Children during the Mathematics Teaching Process. In The Routledge International Handbook of Innovation Education. London: Taylor \& Francis Limited, pp. 315-29.

King, Patricia M., and Matthew J. Mayhew. 2002. Moral Judgement Development in Higher Education: Insights from the Defining Issues Test. Journal of Moral Education 31: 247-70. [CrossRef]

Kingsford, Jess M., David J. Hawes, and Marc de Rosnay. 2018. The Moral Self and Moral Identity: Developmental Questions and Conceptual Challenges. British Journal of Developmental Psychology 36: 652-66. [CrossRef] [PubMed]

Kleinig, John. 1976. Principles of Neutrality in Education*. Educational Philosophy and Theory 8: 1-16. [CrossRef]

Klutz, Philipp, and Noëmi Lakmaier. 2016. Religious Education Faces the Challenge of Religious Plurality: A Qualitative-Empirical Study in Vienna. Religious Diversity and Education in Europe. Münster: Waxmann, vol. 32.

Kohlberg, Lawrence. 1985. The Just Community Approach to Moral Education in Theory and Practice. In Moral Education: Theory and Application. Mahwah: Erlbaum Associates, pp. 27-87.

Kohlberg, Lawrence, and Clark Power. 1981. Moral Development, Religious Thinking, and The Question of a Seventh Stage. Zygon 16: 203-59. [CrossRef]

Lapsley, Daniel. 2015. Moral Identity and Developmental Theory. Human Development 58: 164-71. [CrossRef]

Leijen, Äli, Raili Allas, Auli Toom, Jukka Husu, Juan-José Mena Marcos, Paulien Meijer, Dubravka Knezic, Margus Pedaste, and Edgar Krull. 2014. Guided Reflection for Supporting the Development of Student Teachers' Practical Knowledge. Procedia-Social and Behavioral Sciences 112: 314-22. [CrossRef]

Lester, David. 1993. On the Disunity of the Self: A Systems Theory of Personality. Current Psychology 12: 312-25. [CrossRef]

Levy, Jonathan. 1997. Theatre and Moral Education. Journal of Aesthetic Education 31: 65-75. [CrossRef]

Lickona, Thomas. 1996. Eleven Principles of Effective Character Education. Journal of Moral Education 25: 93-100. [CrossRef]

Lind, Georg. 2008. The Meaning and Measurement of Moral Judgment Competence-A Dual-Aspect Model. In Contemporary Philosophical and Psychological Perspectives on Moral Development and Education. Berlin: Peter Lang, pp. 185-220.

Lind, Georg. 2016. How to Teach Morality: Promoting Deliberation and Discussion, Reducing Violence and Deceit. Berlin: Logos Verlag Berlin.

Lind, Georg, Hans A. Hartmann, and Roland Wakenhut. 2017. Moral Judgments and Social Education, 1st ed. Edited by Hans A. Hartmann. Abingdon: Routledge. [CrossRef] 
Lockwood, Alan L. 1978. The Effects of Values Clarification and Moral Development Curricula on School-Age Subjects: A Critical Review of Recent Research. Review of Educational Research 48: 325-64. [CrossRef]

Maslow, Abraham H. 1943. A Theory of Human Motivation. Psychological Review 50: 370-96. [CrossRef]

Maslow, Abraham H. 2014. Religions, Values, and Peak-Experiences. Bowdon: Stellar Books.

Maslow, Abraham H. 1970. Motivation and Personality, 2nd ed. New York and London: Harper \& Row.

McAdams, Dan P. 1995. What Do We Know When We Know a Person? Journal of Personality 63: 365-96. [CrossRef]

McAdams, Dan P. 1996. Personality, Modernity, and the Storied Self: A Contemporary Framework for Studying Persons. Psychological Inquiry 7: 295-321. [CrossRef]

Moreira-Almeida, Alexander, Francisco Lotufo Neto, and Harold G Koenig. 2006. Religiousness and Mental Health: A Review. Revista Brasileira de Psiquiatria 28: 242-50. [CrossRef] [PubMed]

Moulin, Daniel. 2015. Religious Identity Choices in English Secondary Schools. British Educational Research Journal 41: 489-504. [CrossRef]

Mueller, Claudia M., and Carol S. Dweck. 1998. Praise for Intelligence Can Undermine Children's Motivation and Performance. Journal of Personality and Social Psychology 75: 33-52. [CrossRef]

Narvaez, Darcia, and Daniel K. Lapsley. 2009a. Chapter 8 Moral Identity, Moral Functioning, and the Development of Moral Character. Psychology of Learning and Motivation 50: 237-74. [CrossRef]

Narvaez, Darcia, and Daniel K. Lapsley, eds. 2009b. Personality, Identity, and Character: Explorations in Moral Psychology. Cambridge: Cambridge University Press. [CrossRef]

Neff, Kristin D. 2011. Self-Compassion, Self-Esteem, and Well-Being: Self-Compassion, Self-Esteem, and Well-Being. Social and Personality Psychology Compass 5: 1-12. [CrossRef]

Niemiec, Christopher P., and Richard M. Ryan. 2009. Autonomy, Competence, and Relatedness in the Classroom: Applying SelfDetermination Theory to Educational Practice. Theory and Research in Education 7: 133-44. [CrossRef]

Nussbaum, A. David, and Carol S. Dweck. 2008. Defensiveness Versus Remediation: Self-Theories and Modes of Self-Esteem Maintenance. Personality and Social Psychology Bulletin 34: 599-612. [CrossRef] [PubMed]

Ornstein, Allan C., and Francis P. Hunkins. 1993. Curriculum: Foundations, Principles, and Issues, 2nd ed. Boston: Allyn and Bacon.

Oser, Fritz K. 1994. Chapter 2: Moral Perspectives on Teaching. Review of Research in Education 20: 57-127. [CrossRef]

Palmer, Parker J. 2017. The Courage to Teach: Exploring the Inner Landscape of a Teacher's Life, 20th anniversary ed. Hoboken: Jossey-Bass.

Power, Clark. 2013. Education for Justice and Peace: The Just Community Approach to Moral Education. In Estudos e Pesquisasempsicologia de Desenvolvimento e Da Personalidade: Umahomenagema Angela Biaggio. Floresta: Belo Horizonte, Casa de Psicologo, pp. 63-78.

Preissle, Judith, Glover-Kudon Rebecca, Rohan Elizabeth A., Boehm Jennifer E., and DeGroff Amy. 2015. Putting Ethics on the Mixed Methods Map. In The Oxford Handbook of Multimethod and Mixed Methods Research Inquiry. Oxford: Oxford University Press, pp. 144-62.

Prest, Layne A., Robin Russel, and Henry D’Souza. 1999. Spirituality and Religion in Training, Practice and Personal Development. Journal of Family Therapy 21: 60-77. [CrossRef]

Reeve, Johnmarshall, and Sung Hyeon Cheon. 2021. Autonomy-Supportive Teaching: Its Malleability, Benefits, and Potential to Improve Educational Practice. Educational Psychologist 56: 54-77. [CrossRef]

Regnerus, Mark D., Christian Smith, and Brad Smith. 2004. Social Context in the Development of Adolescent Religiosity. Applied Developmental Science 8: 27-38. [CrossRef]

Reiman, Alan J. 2000. Promoting Reflective Practice within a Cognitive-Structural Framework: Theory, Research and Practice. In International Perspectives on Human Development. Lengerich: Pabst Science Publishers, pp. 506-29.

Reker, Gary T., and Kerry Chamberlain, eds. 2000. Exploring Existential Meaning: Optimizing Human Development across the Life Span. Thousand Oaks: Sage Publications.

Roehlkepartain, Eugene C., Pamela Ebstyne King, Linda M Wagener, and Peter L. Benson. 2006. The Handbook of Spiritual Development in Childhood and Adolescence. Thousand Oaks: SAGE Publications, Inc. [CrossRef]

Rogers, Carl R., Harold C. Lyon, and Reinhard Tausch. 2014. On Becoming an Effective Teacher: Person-Centered Teaching, Psychology, Philosophy, and Dialogues with Carl R. Rogers and Harold Lyon. Londonand New York: Routledge.

Russell, Daniel C. 2009. Practical Intelligence and the Virtues. Oxford: Clarendon Press, New York: Oxford University Press.

Ryan, Richard M., and Edward L. Deci. 2000. Self-Determination Theory and the Facilitation of Intrinsic Motivation, Social Development, and Well-Being. American Psychologist 55: 68-78. [CrossRef]

Ryan, Richard M., and Edward L. Deci. 2006. Self-Regulation and the Problem of Human Autonomy: Does Psychology Need Choice, Self-Determination, and Will? Journal of Personality 74: 1557-86. [CrossRef]

Sarivan, Ligia. 2011. The Reflective Teacher. Procedia-Social and Behavioral Sciences 11: 195-99. [CrossRef]

Saunders, Harold H. 2001. A Public Peace Process: Sustained Dialogue to Transform Racial and Ethnic Conflicts. Basingstoke and New York: Palgrave, Available online: http:/ / site.ebrary.com/id/10023010 (accessed on 4 June 2021).

Schreiner, Peter. 2014. Religion in Education: Innovation in International Research. British Journal of Religious Education 36: 106-8. [CrossRef]

Schremer, Oded E. 1992. Moral Education Programmes: A Curriculum Perspective. Journal of Moral Education 21: 151-60. [CrossRef]

Schutzman, Mady, and Jan Cohen-Cruz, eds. 1994. Playing Boal: Theatre, Therapy, Activism. London: New York: Routledge. 
Seligman, Martin E. P. 1992. Helplessness: On Depression, Development, and Death. A Series of Books in Psychology; New York: W. H. Freeman.

Selman, Robert L. 1971. The Relation of Role Taking to the Development of Moral Judgment in Children. Child Development 42: 79. [CrossRef] [PubMed]

Selman, Robert L. 1976. Social-Cognitive Understanding: A Guide to Educational and Clinical Practice. In Moral Development and Behavior. New York: Holt, Rinehart and Winston, pp. 299-316.

Simpson, David, and David Beckett. 2014. Expertise, Pedagogy and Practice. Educational Philosophy and Theory 46: 563-68. [CrossRef]

Sutherland, Kevin S., Nirbhay N. Singh, Kevin S. Sutherland, Maureen Conroy, and Janine Peck Stichter. 2004. Learned Helplessness and Students with Emotional or Behavioral Disorders: Deprivation in the Classroom. Behavioral Disorders 29: 169-81. [CrossRef]

Sutton, Geoffrey W., and Brandon Schmidly, eds. 2016. Christian Morality: An Interdisciplinary Framework for Thinking about Contemporary Moral Issues. Eugene: Pickwick Publications.

Tengland, Per-Anders. 2001. Marie Jahoda's Current Concepts of Positive Mental Health. In Mental Health. Edited by Per-Anders Tengland. Dordrecht: Springer Netherlands, pp. 47-78. [CrossRef]

Thambu, Nadarajan, and Muhammad Hasbi Abdul Rahman. 2017. Forum Theatre as a Behavior Change Strategy: Qualitative Findings from Moral Education Class. The Journal of the South East Asia Research Centre for Communications and Humanities 9: 25-46.

Uecker, Jeremy E., Mark D. Regnerus, and Margaret J. Vaaler. 2007. Losing My Religion: The Social Sources of Religious Decline in Early Adulthood. Social Forces 85: 1667-92. [CrossRef]

Usán Supervía, Pablo, Carlos Salavera Bordás, and Víctor Murillo Lorente. 2020. Exploring the Psychological Effects of Optimism on Life Satisfaction in Students: The Mediating Role of Goal Orientations. International Journal of Environmental Research and Public Health 17: 7887. [CrossRef]

Weber, Samuel R., and Kenneth I. Pargament. 2014. The Role of Religion and Spirituality in Mental Health. Current Opinion in Psychiatry 27: 358-63. [CrossRef]

Wildová, Radka. 2015. Monitoring the Use of Innovative Psycho-Didactic Processes in Reading Literacy Development. Procedia-Social and Behavioral Sciences 171: 60-65. [CrossRef]

Winzer, Regina, Lene Lindberg, Karin Guldbrandsson, and Anna Sidorchuk. 2018. Effects of Mental Health Interventions for Students in Higher Education Are Sustainable over Time: A Systematic Review and Meta-Analysis of Randomized Controlled Trials. PeerJ 6: e4598. [CrossRef] [PubMed]

Wojciszke, Bogdan, Roza Bazinska, and Marcin Jaworski. 1998. On the Dominance of Moral Categories in Impression Formation. Personality and Social Psychology Bulletin 24: 1251-63. [CrossRef] 